\title{
ARMS AND INFLUENCE
}

Written under the auspices of the Center for International Affairs Harvard University

Delivered in part as the Henry L. Stimson Lectures Yale University 
This page intentionally left blank 

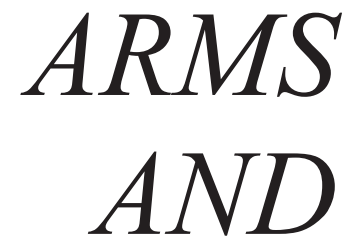

\section{INFLUENCE}

With a New Introduction by Anne-Marie Slaughter

\section{BY THOMAS C. SCHELLING}

A VERITAS PAPERBACK

Yale UNIVERSITY PRESS

NEW HAVEN AND LONDON 
Veritas paperback edition, 2020

Copyright (C) 1966 by Yale University.

Preface to the 2008 edition (C) 2008 by Yale University.

Introduction to the Veritas paperback edition copyright (C) 2020 by

Anne-Marie Slaughter.

All rights reserved. This book may not be reproduced, in whole or in part, including illustrations, in any form (beyond that copying permitted by Sections 107 and 108 of the U.S. Copyright Law and except by reviewers for the public press), without written permission from the publishers.

Arms and Influenc was originally published in 1966 by Yale University Press and reissued with a new preface in 2008.

Printed in the United States of America.

Library of Congress Control Number: 2008925430

ISBN 978-0-300-24674-2 (pbk.)

A catalogue record for this book is available from the British Library.

10987654321 